\title{
The inhibition effect of sodium tetraborate on the corrosion of steel in $\mathrm{KOH}$ media
}

\author{
G.S. Öz and S. Bilgiç* \\ Department of Chemistry, Faculty of Science, Ankara University, Ankara, Turkey \\ *E-mail: bilgic@science.ankara.edu.tr
}

\begin{abstract}
In this study, the inhibition effect of sodium tetraborate $\left(\mathrm{Na}_{2} \mathrm{~B}_{4} \mathrm{O}_{7} \cdot 10 \mathrm{H}_{2} \mathrm{O}\right)$ on the corrosion of steel has been investigated in $3 \%$ and $5 \% \mathrm{KOH}$ media. Corrosion parameters have been determined using Tafel extrapolation and impedance spectroscopy methods by the addition of $1 \%-7 \% \mathrm{Na}_{2} \mathrm{~B}_{4} \mathrm{O}_{7}$ into two concentrations of $\mathrm{KOH}$ solutions. It has been found that the inhibition efficiency of $\mathrm{Na}_{2} \mathrm{~B}_{4} \mathrm{O}_{7}$ in both $\mathrm{KOH}$ media increases in $1 \%-4 \%$ concentration range whereas it decreases in 5\%-7\% concentration range. However, corrosion rates are less than when the corrosion media does not contain the inhibitor. The effect of temperature on the corrosion rate of steel and the inhibition effect of $\mathrm{Na}_{2} \mathrm{~B}_{4} \mathrm{O}_{7}$ concentration have also been investigated by carrying out each experiment at four different temperatures, i.e., $25^{\circ} \mathrm{C}, 40^{\circ} \mathrm{C}, 55^{\circ} \mathrm{C}$ and $70^{\circ} \mathrm{C}$. Corrosion rates have been observed to increase with temperature and $\mathrm{KOH}$ concentration both in $3 \%$ and $5 \%$ media. $\mathrm{Na}_{2} \mathrm{~B}_{4} \mathrm{O}_{7}$ is an effective inhibitor at low temperature for steel. According to scanning electron micrograph (SEM) images obtained by adding $4 \% \mathrm{Na}_{2} \mathrm{~B}_{4} \mathrm{O}_{7}$ into both $\mathrm{KOH}$ media for bare steel and steel, pitting corrosion occurs on the metal surface. Experimental results support SEM images. $\mathrm{H}_{2}$ flows in $3 \%$ and $5 \% \mathrm{KOH}$ media have been investigated using gasometric measurement depending on the concentration of $\mathrm{Na}_{2} \mathrm{~B}_{4} \mathrm{O}_{7}$ by a flowmeter and it has been observed that $\mathrm{H}_{2}$ flow rate decreases in $1 \%-4 \%$ inhibitor concentration range for both $\mathrm{KOH}$ whereas it remains fixed in $5 \%-7 \%$ concentration range especially in $5 \% \mathrm{KOH}$ solution. This finding is consistent with the values found by determining corrosion rates and inhibition efficiencies.
\end{abstract}

Received: April 26, 2018. Published: August 29, 2018

doi: $\underline{10.17675 / 2305-6894-2018-7-3-9}$

Keywords: corrosion, inhibitor, steel, sodium tetraborate. 


\section{Introduction}

Corrosion is the deterioration of a metal by chemical and electrochemical reaction. Corrosion is undesirable phenomenon; because it is a slowly progressive process, thus its harmful consequences occur in a long time. Corrosion is an important factor that determines the cost of production and investment in industry. Infrastructure items such as pipelines, bridges, automobiles, storage tanks, airplanes and ships can be significantly damaged and eventually destroyed by corrosion. According to some estimates, the cost of corrosion to a country is at a level of 3.5-5.0\% of gross national product.

There are several methods to prevent and/or reduce corrosion, such as painting, cathodic protection, anodic protection, adding chemical compounds called inhibitors. The use of corrosion inhibitors is considered as the most effective method for the protection of many metals and alloys against corrosion [1-3]. Inhibitors prevent corrosion either by being adsorbed on the surface of metals and alloys, or by forming a protective layer or by causing the formation of insoluble complex. However, most of these compounds are toxic and using them is harmful for human health and environment. Therefore, their usage is limited in practice. Steels are considered to be the most important metals which are frequently used in different industrial applications. Despite of the presence of several studies on the usage of organic compounds as inhibitor to protect of iron and steels [4-16], the studies with inorganic compounds are less [17-22]. The cost of inorganic inhibitors is low, but most of them contain chromate, nitrite and arsenate that have toxic and carcinogenic properties [23-26].

Boron, which is defined by many scientists as "the petroleum of $21^{\text {st }}$ century", is an indispensable raw material in several areas such as space technology, information industry, nuclear technology and war industry. It is used to provide mechanical functions such as high strength, lightness, heat resistance in areas such as aerospace, aviation, automotive, railway, concrete repair and reinforcement, nuclear reactors, gas turbines, heat exchangers, rocket nozzles, etc. Boron minerals are classified according to $\mathrm{Ca}, \mathrm{Na}$ and $\mathrm{Mg}$ elements found in their structures, and they are evaluated in terms of their $\mathrm{B}_{2} \mathrm{O}_{3}$ percentage. Boron minerals with the highest $\mathrm{B}_{2} \mathrm{O}_{3}$ rates are very merchantable.

One of the cheapest boron compounds is sodium tetraborate, and accordingly, is chosen as an inhibitor in this study. Furthermore, it does not have toxic effects, and there are only a few of studies $[27,28]$ on the inhibition efficiency of this compound which makes this research important.

In this study, the inhibition effects of sodium tetraborate on the corrosion of steel in both $3 \%$ and $5 \% \mathrm{KOH}$ media have been investigated depending on concentration and temperature. 


\section{Methods and materials}

The chemical composition of steel employed in this study is given in Table 1 . The $4 \mathrm{~mm}$ diameter steel electrode was cut and embedded in a cold-curing resin on a methyl methacrylate basis (Technovit, Kulzer, Friedrichsdorf, Germany). Before each experiment, the steel surface was abraded with a 1200 grid emery paper, washed with bi-distilled water and then put into the center of three armed Pyrex cell. Saturated calomel electrode (SCE) and $\mathrm{Pt}$ foil were used as reference and counter electrode, respectively. The reference and the working electrode compartments were separated from each other by a Luggin capillary and stopcock. Solutions were prepared by bi-distilled water and all the chemicals were chemically pure.

Table 1. The chemical composition (wt \%) of studied steel electrode.

\begin{tabular}{cccccccc}
\hline $\mathbf{C}$ & $\mathbf{S i}$ & $\mathbf{M n}$ & $\mathbf{P}$ & $\mathbf{S}$ & $\mathbf{C r}$ & $\mathbf{N i}$ & $\mathbf{F e}$ \\
\hline 0.03 & 1.01 & 2.03 & 0.042 & 0.03 & 18.76 & 8.58 & 69.52 \\
\hline
\end{tabular}

Nitrogen gas bubbled through the solution for 20 minutes for removing oxygen gas before and throughout the experiment.

Experiments were performed with two methods such as potentiostatic method and alternative current impedance spectroscopy method. The potential scan rate was chosen as $5 \mathrm{mVs}^{-1}$. In the potentiostatic method, the corrosion parameters were determined by Tafel extrapolation method, the corrosion parameters were determined from current-potential curves in $3 \%$ and $5 \% \mathrm{KOH}$ solutions. These experiments were repeated at $25^{\circ}, 40^{\circ}, 55^{\circ}$ and $70^{\circ} \mathrm{C}$ temperatures. Current-potential curves were obtained by IVIUMSTAT/ potentiostat/galvanostat. The impedance measurements obtained as Nyquist curves at $25^{\circ} \mathrm{C}$ temperature in 3\% and 5\% $\mathrm{KOH}$ media. The impedance curves were obtained by $\mathrm{CH} 66 \mathrm{OC}$ in the range of $1-10000 \mathrm{~Hz}$ frequency. Results were repeated at least three times.

\section{Results and Discussion}

The current-potential curves are given for steel at $25^{\circ} \mathrm{C}$ in $3 \% \mathrm{KOH}$ medium and by adding $1 \%-4 \%$ and $5 \%-7 \% \mathrm{Na}_{2} \mathrm{~B}_{4} \mathrm{O}_{7}$ into this medium are seen in Figures $1 \mathrm{a}$ and $1 \mathrm{~b}$. The current-potential curves obtained for steel in $5 \% \mathrm{KOH}$ medium and also by adding $1 \%-4 \%$ and $5 \%-7 \% \mathrm{Na}_{2} \mathrm{~B}_{4} \mathrm{O}_{7}$ into this medium at the same temperature are given in Figures $2 \mathrm{a}$ and $2 \mathrm{~b}$, respectively. 


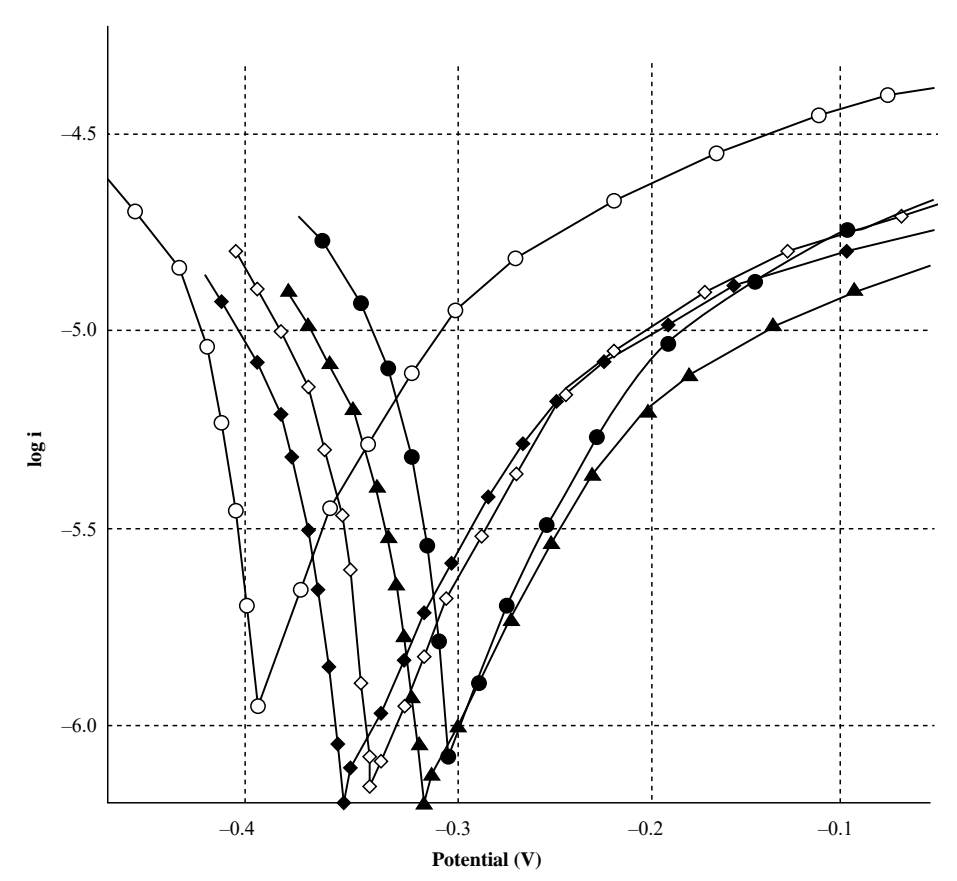

Figure 1a. The current-potential curves in the concentration range of $1 \%-4 \% \mathrm{Na}_{2} \mathrm{~B}_{4} \mathrm{O}_{7}$ in

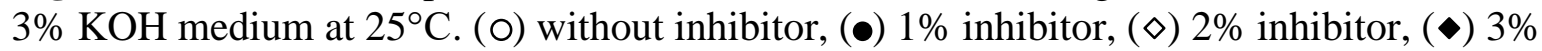
inhibitor, (ム) $4 \%$ inhibitor.

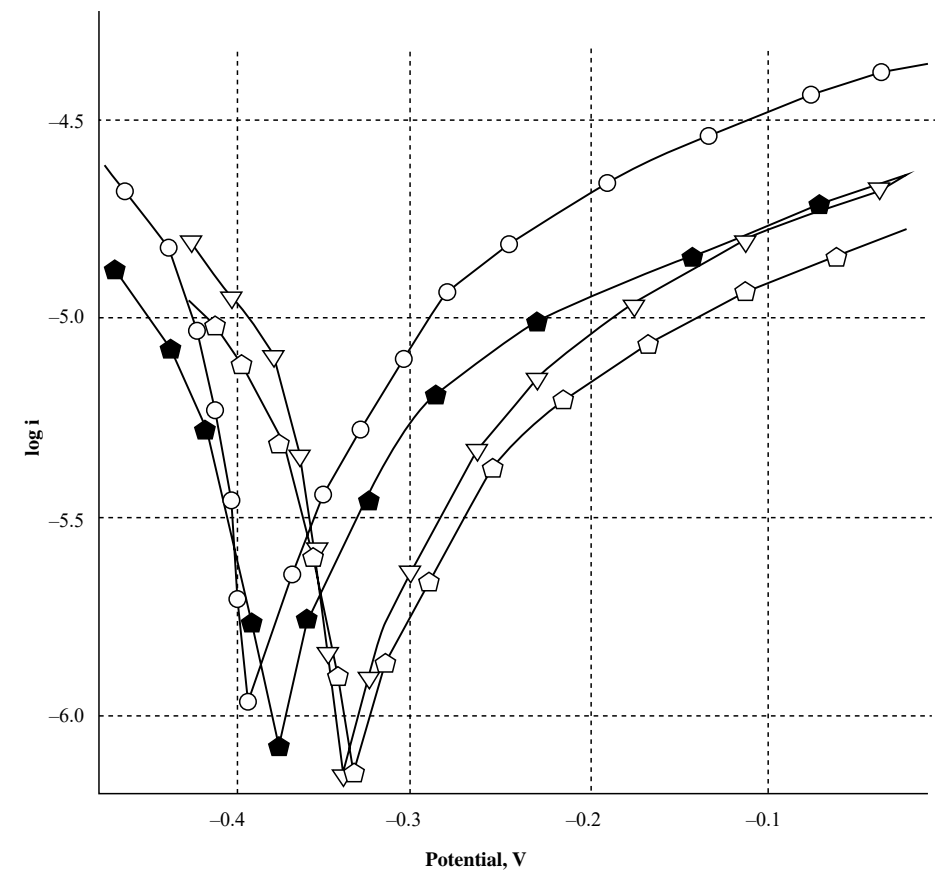

Figure 1b. The current-potential curves in the concentration range of $5 \%-7 \% \mathrm{Na}_{2} \mathrm{~B}_{4} \mathrm{O}_{7}$ in $3 \% \mathrm{KOH}$ medium at $25^{\circ} \mathrm{C}$. (०) without inhibitor, ( $\left.\nabla\right) 5 \%$ inhibitor, (๑) $6 \%$ inhibitor, (•) $7 \%$ inhibitor. 


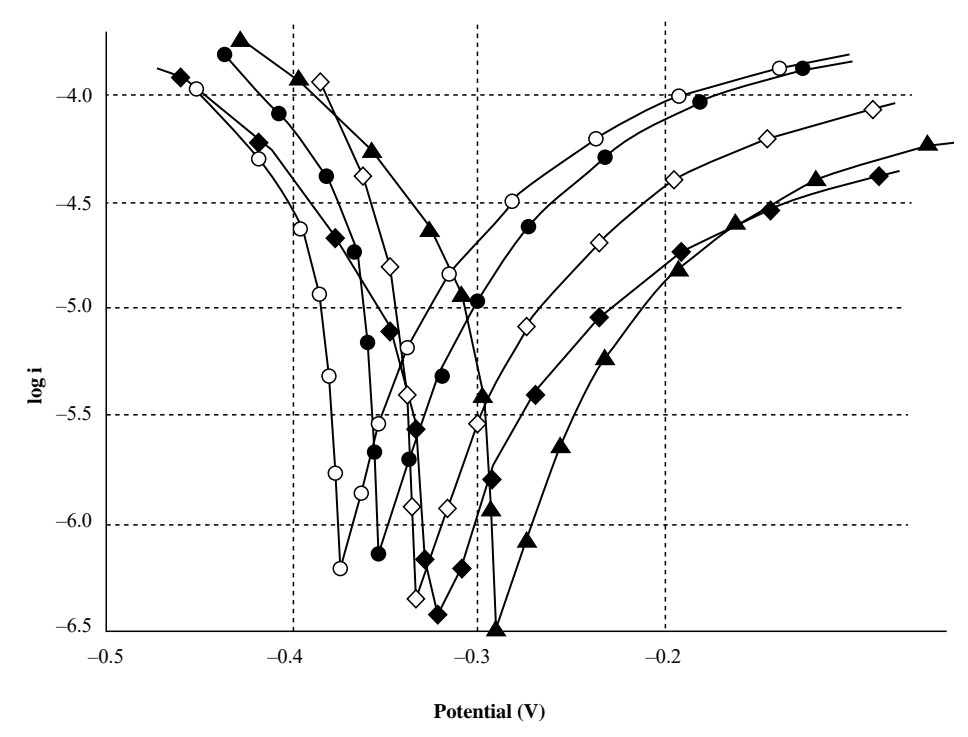

Figure 2a. The current-potential curves in the concentration range of $1 \%-4 \% \mathrm{Na}_{2} \mathrm{~B}_{4} \mathrm{O}_{7}$ in

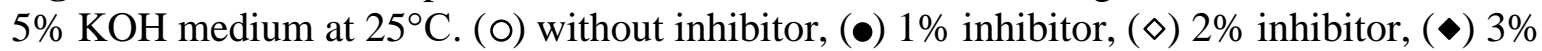
inhibitor, (ム) $4 \%$ inhibitor.

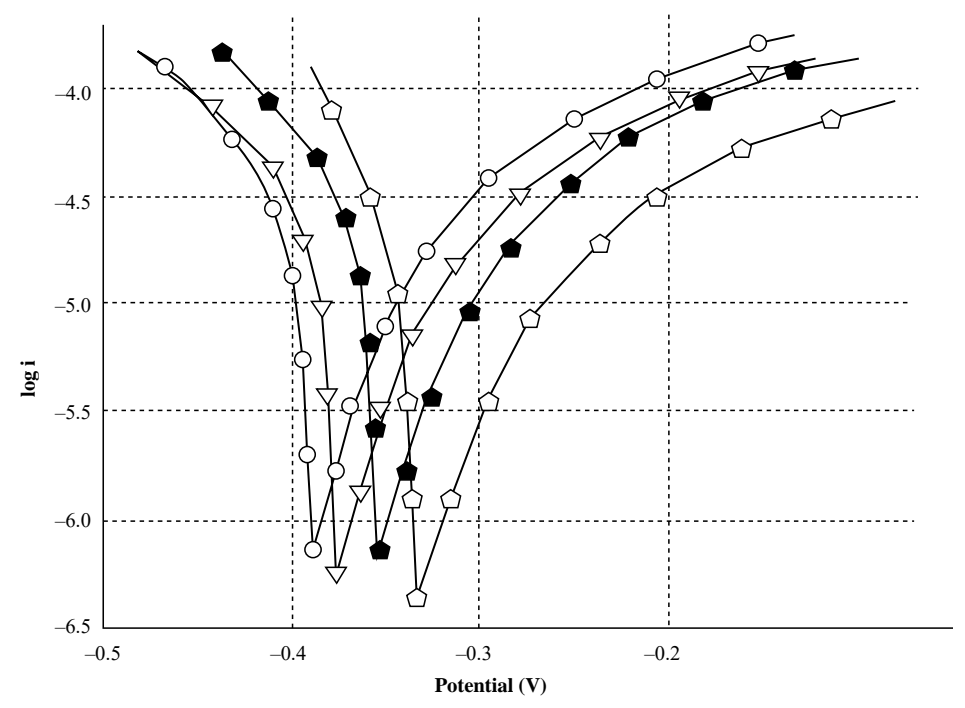

Figure 2b. The current-potential curves in the concentration range of $5 \%-7 \% \mathrm{Na}_{2} \mathrm{~B}_{4} \mathrm{O}_{7}$ in $5 \% \mathrm{KOH}$ medium at $25^{\circ} \mathrm{C}$. (०) without inhibitor, ( $\left.\nabla\right) 5 \%$ inhibitor, (๑) $6 \%$ inhibitor, (•) $7 \%$ inhibitor.

Figures $3 \mathrm{a}$ and $3 \mathrm{~b}$ show the current-potential curves of steel in $3 \% \mathrm{KOH}$ and by adding the same concentration range of $\mathrm{Na}_{2} \mathrm{~B}_{4} \mathrm{O}_{7}$ into this medium at $70^{\circ} \mathrm{C}$. The current-potential curves obtained in $5 \% \mathrm{KOH}$ medium and also by adding $1 \%-4 \%$ and $5 \%-7 \% \mathrm{Na}_{2} \mathrm{~B}_{4} \mathrm{O}_{7}$ into this medium at $70^{\circ} \mathrm{C}$ can be seen in Figures $4 \mathrm{a}$ and $4 \mathrm{~b}$. 


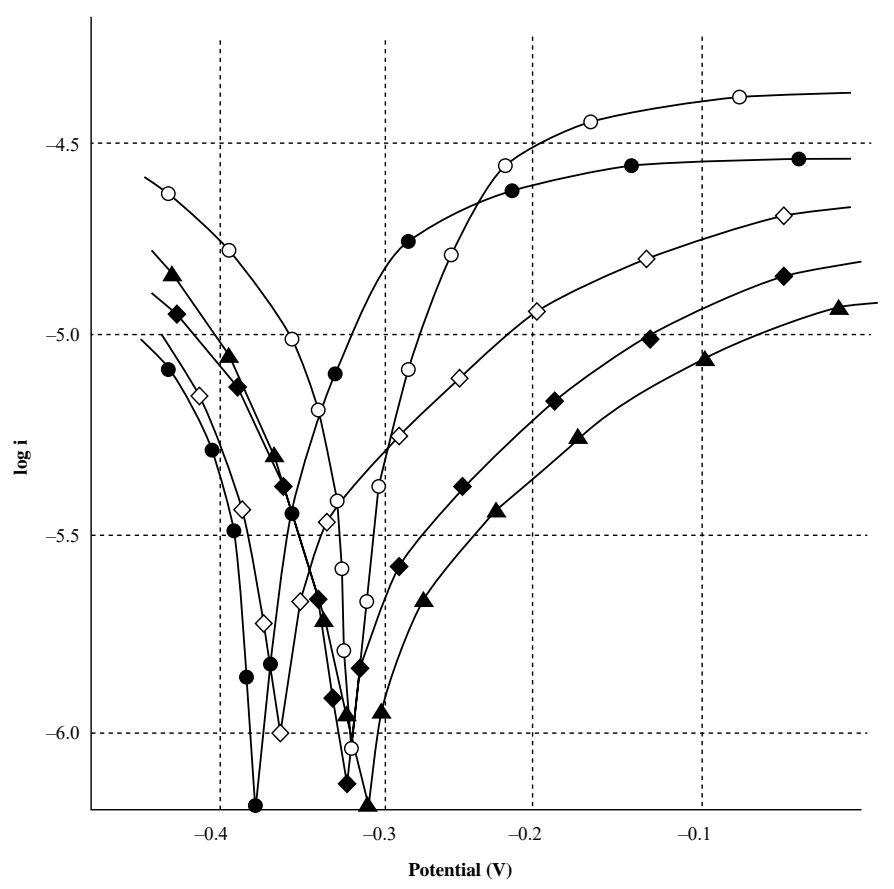

Figure 3a. The current-potential curves in the concentration range of $1 \%-4 \% \mathrm{Na}_{2} \mathrm{~B}_{4} \mathrm{O}_{7}$ in $3 \% \mathrm{KOH}$ medium at $70^{\circ} \mathrm{C}$. (০) without inhibitor, $(\bullet) 1 \%$ inhibitor, $(\diamond) 2 \%$ inhibitor, $(\diamond) 3 \%$ inhibitor, (৯) $4 \%$ inhibitor.

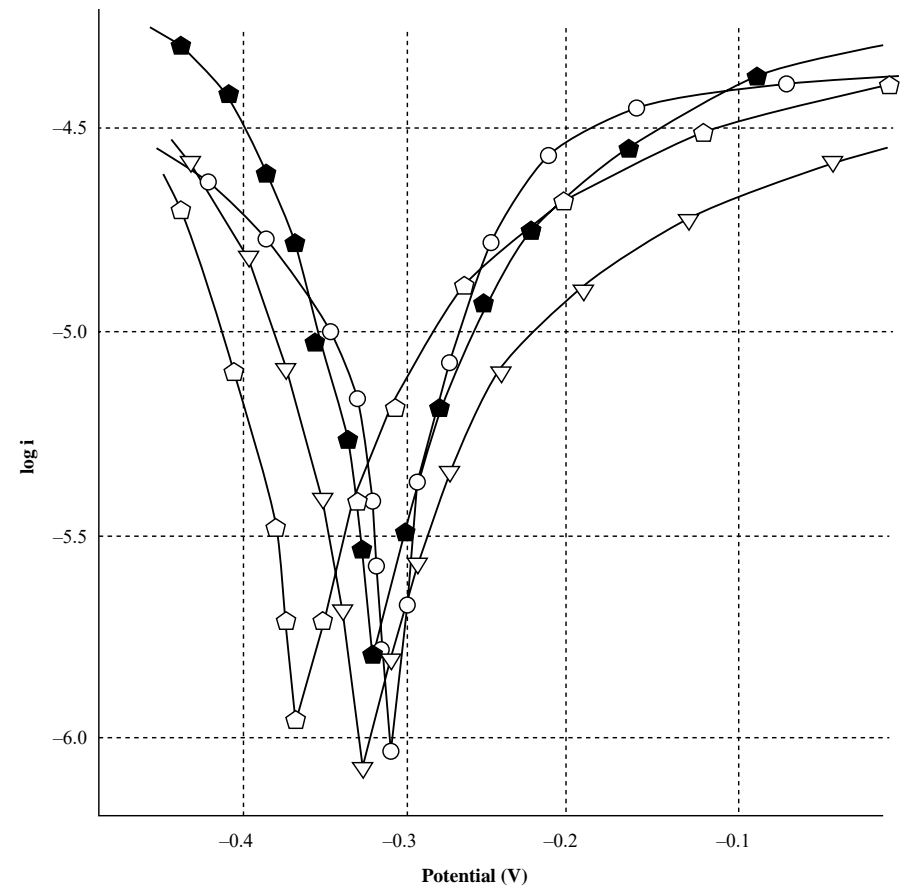

Figure 3b. The current-potential curves in the concentration range of $5 \%-7 \% \mathrm{Na}_{2} \mathrm{~B}_{4} \mathrm{O}_{7}$ in $3 \% \mathrm{KOH}$ medium at $70^{\circ} \mathrm{C}$. (০) without inhibitor, ( $(\nabla) 5 \%$ inhibitor, (๑) $6 \%$ inhibitor, (•) $7 \%$ inhibitor. 


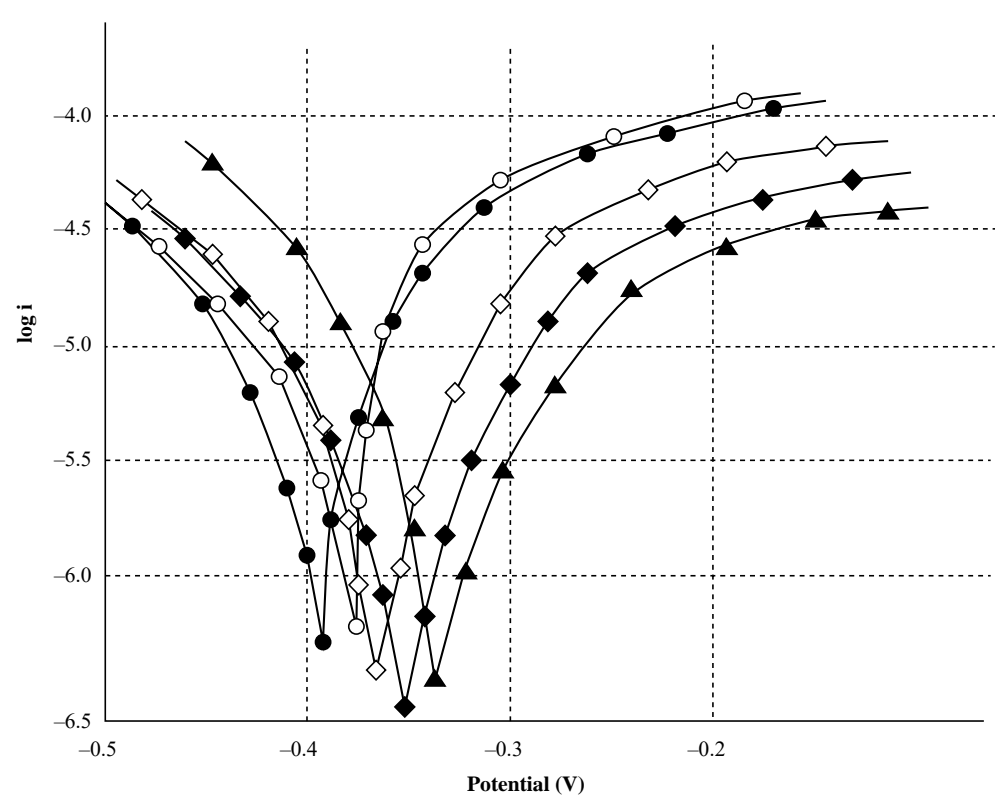

Figure 4a. The current-potential curves in the concentration range of $1 \%-4 \% \mathrm{Na}_{2} \mathrm{~B}_{4} \mathrm{O}_{7}$ in


inhibitor, (৯) $4 \%$ inhibitor.



Figure 4b. The current-potential curves in the concentration range of $1 \%-4 \% \mathrm{Na}_{2} \mathrm{~B}_{4} \mathrm{O}_{7}$ in $5 \% \mathrm{KOH}$ medium at $70^{\circ} \mathrm{C}$. (०) without inhibitor, ( $\left.\nabla\right) 5 \%$ inhibitor, (๑) $6 \%$ inhibitor, (•) $7 \%$ inhibitor. 
From the potentiostatic current-potential curves, corrosion parameters such as corrosion potentials $\left(E_{\text {corr }}\right)$, anodic and cathodic Tafel slopes $\left(\beta_{\mathrm{a}}\right.$ and $\left.\beta_{\mathrm{c}}\right)$, corrosion current densities $\left(i_{\text {corr }}\right)$ and percent inhibition efficiencies $(\eta \%)$ were determined depending on inhibitor concentration in $3 \%$ and $5 \% \mathrm{KOH}$ media (Tables 2 and 3 ) at $25^{\circ} \mathrm{C}$. The same parameters in $3 \% \mathrm{KOH}$ and $5 \% \mathrm{KOH}$ are shown in Tables 4 and 5 respectively at $70^{\circ} \mathrm{C}$.

Table 2. The corrosion parameters determined depending on inhibitor concentration in $3 \% \mathrm{KOH}$ media at $25^{\circ} \mathrm{C}$.

\begin{tabular}{cccccc}
\hline $\begin{array}{c}\text { Inhibitor } \\
\text { concentration }(\boldsymbol{\%})\end{array}$ & $-\boldsymbol{E}_{\text {corr }}(\mathbf{m V})$ & $\boldsymbol{i}_{\text {corr }}\left(\boldsymbol{\mu A} / \mathbf{c m}^{2}\right) \times \mathbf{1 0}^{-\mathbf{6}}$ & $\boldsymbol{\beta}_{\mathrm{a}}$ & $\boldsymbol{\beta}_{\mathrm{c}}$ & $\boldsymbol{\eta} \%$ \\
\hline 0 & 379 & 2.77 & 43 & 110 & - \\
1 & 366 & 1.99 & 38 & 107 & 28 \\
2 & 353 & 1.79 & 35 & 106 & 35 \\
3 & 359 & 1.58 & 41 & 108 & 43 \\
4 & 347 & 1.35 & 17 & 143 & 51 \\
5 & 361 & 1.44 & 41 & 103 & 48 \\
7 & 353 & 1.80 & 44 & 112 & 35 \\
\hline
\end{tabular}

Table 3. The corrosion parameters determined depending on inhibitor concentration in $5 \% \mathrm{KOH}$ media at $25^{\circ} \mathrm{C}$.

\begin{tabular}{cccccc}
\hline $\begin{array}{c}\text { Inhibitor } \\
\text { concentration (\%) }\end{array}$ & $-\boldsymbol{E}_{\text {corr }}(\mathbf{m V})$ & $\boldsymbol{i}_{\text {corr }}\left(\boldsymbol{\mu} \mathbf{A} / \mathbf{c m}^{\mathbf{2}}\right) \times \mathbf{1 0}^{-\mathbf{6}}$ & $\boldsymbol{\beta}_{\mathrm{a}}$ & $\boldsymbol{\beta}_{\mathrm{c}}$ & $\boldsymbol{\eta} \%$ \\
\hline 0 & 380 & 3.89 & 56 & 109 & - \\
1 & 371 & 2.51 & 44 & 104 & 35 \\
2 & 374 & 2.24 & 41 & 112 & 42 \\
3 & 369 & 2.14 & 47 & 107 & 45 \\
4 & 372 & 1.38 & 49 & 110 & 64 \\
5 & 384 & 1.47 & 50 & 111 & 62 \\
7 & 381 & 1.66 & 58 & 107 & 57 \\
\hline
\end{tabular}


Table 4. The corrosion parameters determined depending on inhibitor concentration in $3 \% \mathrm{KOH}$ media at $70^{\circ} \mathrm{C}$.

\begin{tabular}{cccccc}
\hline $\begin{array}{c}\text { Inhibitor } \\
\text { concentration }(\boldsymbol{\%})\end{array}$ & $-\boldsymbol{E}_{\text {corr }}(\mathbf{m V})$ & $\boldsymbol{i}_{\text {corr }}\left(\boldsymbol{\mu} \mathbf{A} / \mathbf{c m}^{\mathbf{2}}\right) \times \mathbf{1 0}^{-\mathbf{6}}$ & $\boldsymbol{\beta}_{\mathbf{a}}$ & $\boldsymbol{\beta}_{\mathbf{c}}$ & $\boldsymbol{\eta} \%$ \\
\hline 0 & 353 & 5.49 & 64 & 118 & - \\
1 & 368 & 3.55 & 53 & 120 & 35 \\
2 & 371 & 2.63 & 51 & 116 & 52 \\
3 & 360 & 1.90 & 47 & 109 & 65 \\
4 & 355 & 1.51 & 43 & 108 & 72 \\
5 & 349 & 3.54 & 51 & 117 & 35 \\
6 & 362 & 4.36 & 56 & 118 & 20 \\
7 & 356 & 4.78 & 53 & 106 & 12 \\
\hline
\end{tabular}

Table 5. The corrosion parameters determined depending on inhibitor concentration in 5\% $\mathrm{KOH}$ media at $70^{\circ} \mathrm{C}$.

\begin{tabular}{|c|c|c|c|c|c|}
\hline $\begin{array}{c}\text { Inhibitor } \\
\text { concentration }(\%)\end{array}$ & $-E_{\text {corr }}(\mathrm{mV})$ & $i_{\text {corr }}\left(\mu \mathrm{A} / \mathrm{cm}^{2}\right) \times 10^{-6}$ & $\beta_{\mathrm{a}}$ & $\beta_{c}$ & $\eta \%$ \\
\hline 0 & 384 & 5.60 & 77 & 121 & - \\
\hline 1 & 393 & 3.72 & 64 & 118 & 33 \\
\hline 2 & 391 & 2.51 & 63 & 120 & 55 \\
\hline 3 & 396 & 2.137 & 60 & 119 & 61 \\
\hline 4 & 401 & 1.512 & 58 & 106 & 73 \\
\hline 5 & 400 & 3.08 & 53 & 117 & 45 \\
\hline 6 & 399 & 3.584 & 48 & 112 & 36 \\
\hline 7 & 403 & 3.808 & 43 & 116 & 32 \\
\hline
\end{tabular}

The percentage inhibition efficiencies $(\eta \%)$ were calculated using the following formula

$$
\eta=\left|\frac{i-i_{0}}{i}\right| \cdot 100
$$

where $i_{0}$ and $i$ are the current densities in the absence and presence of the inhibitor, respectively. 
As can be seen from curves and tables in both $3 \%$ and $5 \% \mathrm{KOH}$ media, in the range of $1 \%-4 \%$ inhibitor concentration, corrosion potentials do not show regular variation, while corrosion current densities decrease, inhibition efficiencies increase. The corrosion current densities (corrosion rates) of steel are less than that of corrosion rates without inhibitor, these values have been found to be more than in the inhibitor concentration range studied. 1/T-log $i$ graphs obtained in the presence of different concentrations of $\mathrm{Na}_{2} \mathrm{~B}_{4} \mathrm{O}_{7}$ in $3 \%$ and $5 \% \mathrm{KOH}$ media are given in Figures 5 and 6.

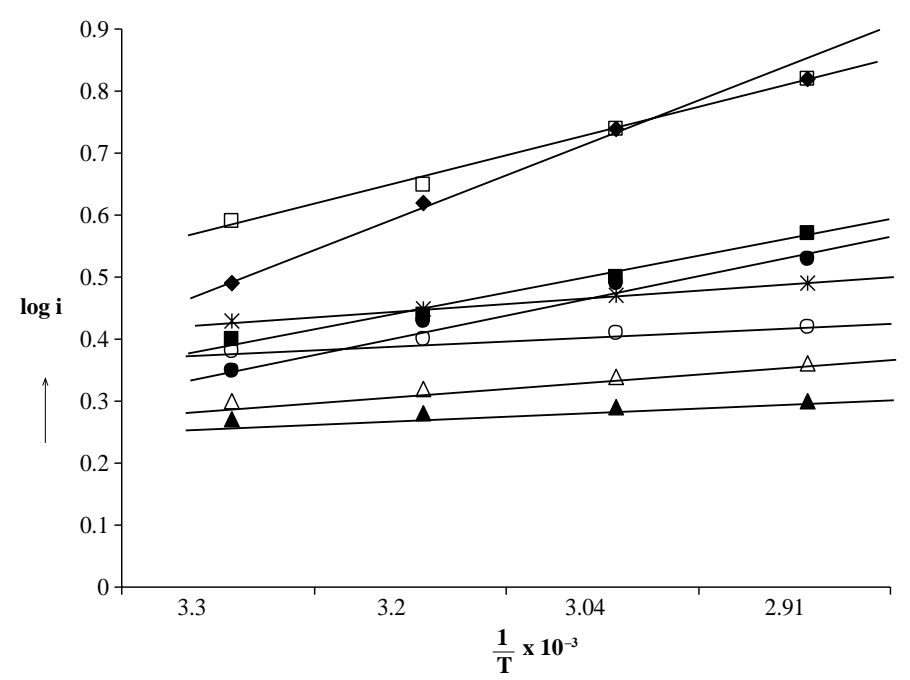

Figure 5. The $1 / T-\log i$ graphs obtained for steel at different temperatures according to the concentrations of $\mathrm{Na}_{2} \mathrm{~B}_{4} \mathrm{O}_{7}$ in $5 \% \mathrm{KOH}$ medium. (•) $0,(\boldsymbol{\bullet}) 1,(\bullet) 2,(\Delta) 3,(\Delta) 4,(\mathrm{o}) 5,(*) 6$, (ㅁ) 7 .

The corrosion rates increase with increasing temperature at the same inhibitor concentration in both $3 \% \mathrm{KOH}$ and $5 \% \mathrm{KOH}$ media. Activation energy can be calculated from Arrhenius equation given as follow.

$$
i=k \exp \left(-\frac{E_{\mathrm{a}}}{R T}\right)
$$

In this equation, $E_{\mathrm{a}}$ is the activation energy, $k$ is a constant, $R$ and $T$ are gas constant and absolute temperature, respectively. The activation energies were calculated using the Equation 2.1/T-log $i$ graphs are given in Figures 5 and 6. For example, the $E_{\mathrm{a}}$ value of $10770.3 \mathrm{~J} \mathrm{~mol}^{-1}$ in $3 \% \mathrm{KOH}$ was found to be $12765 \mathrm{~J} \mathrm{~mol}^{-1}$ in the presence of $2 \%$ inhibitor concentration, whereas these energies have been found to be 9674 and $10172 \mathrm{~J} \mathrm{~mol}^{-1}$ in 5\% $\mathrm{KOH}$ respectively. These results show that $\mathrm{Na}_{2} \mathrm{~B}_{4} \mathrm{O}_{7}$ used as inhibitor increases the 
potential energy barrier, and accordingly, the corrosion is reduced. This change indicates that the active sites on the metal surface are blocked.

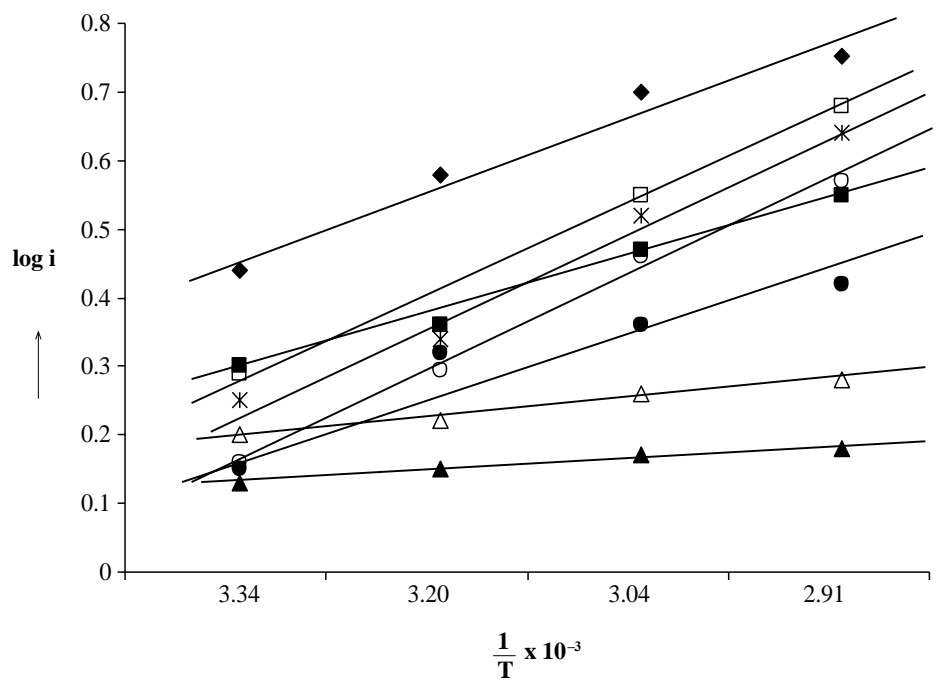

Figure 6. The $1 / T-\log i$ graphs obtained for steel at different temperatures according to the concentrations of $\mathrm{Na}_{2} \mathrm{~B}_{4} \mathrm{O}_{7}$ in $5 \% \mathrm{KOH}$ medium. (•) $0,(\bullet) 1,(\bullet) 2,(\Delta) 3,(\Delta) 4,(\circ) 5,(*) 6$, (口) 7.

In this study, Nyquist curves were obtained with alternative current impedance method for supporting the data determined with Tafel extrapolation method. The Nyquist curves obtained of the steel in $3 \% \mathrm{KOH}$ and $5 \% \mathrm{KOH}$ solutions and adding different percentage of $\mathrm{Na}_{2} \mathrm{~B}_{4} \mathrm{O}_{7}$ are seen in Figures 7 and 8.

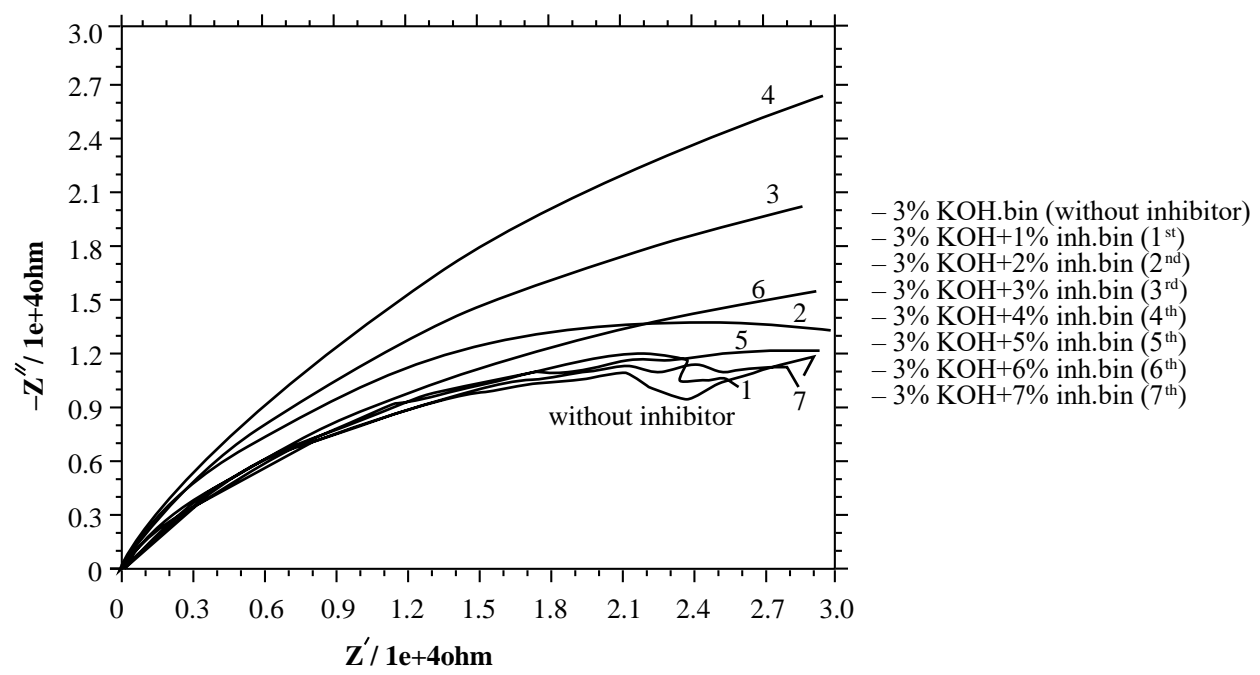

Figure 7. The Nyquist curves in the presence of different concentrations of inhibitor in $3 \%$ $\mathrm{KOH}$ at $25^{\circ} \mathrm{C}$. 


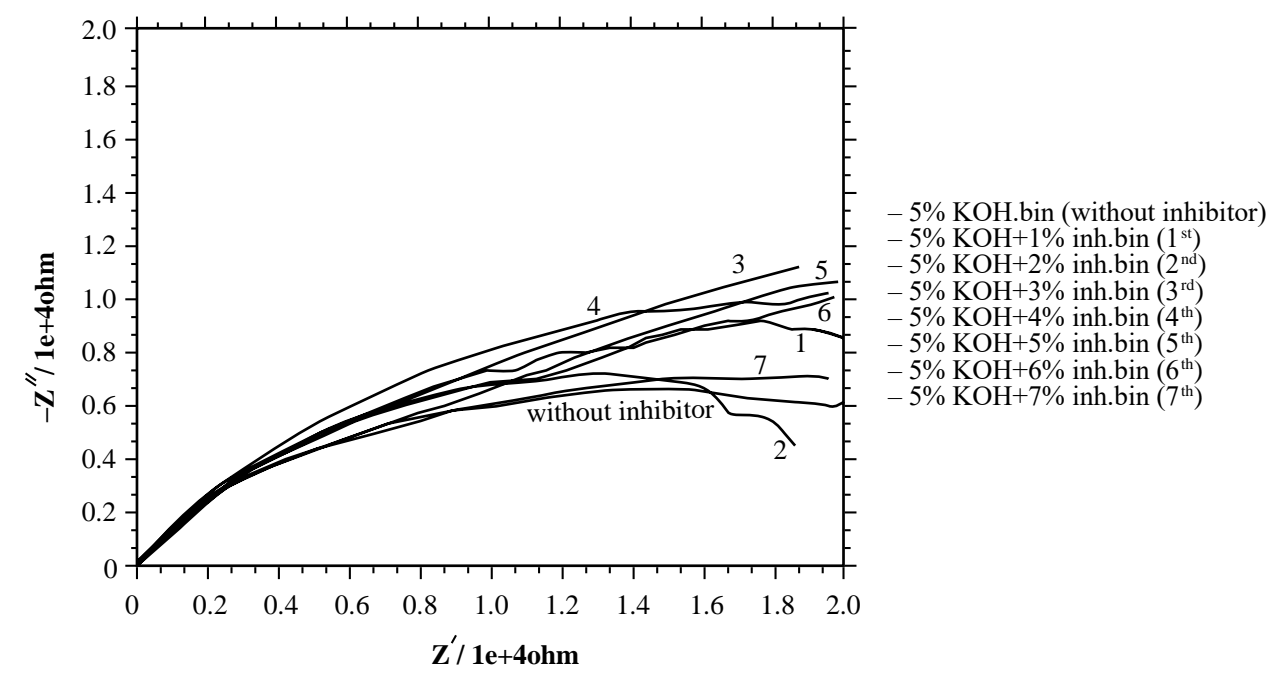

Figure 8. The Nyquist curves in the presence of different concentrations of inhibitor in $5 \%$ $\mathrm{KOH}$ at $25^{\circ} \mathrm{C}$.

The inhibition efficiencies determined with impedance spectroscopy method in 3\% $\mathrm{KOH}$ medium at $25^{\circ} \mathrm{C}$ are seen in Table $6 . R_{\mathrm{p}}$ values given in this table were found from Nyquist curves by helping correlation using $\mathrm{CH} 66 \mathrm{OC}$ analyzer. Percent inhibition values were determined by these curves. These values are in accordance with the results of Tafel extrapolation method.

Table 6. The inhibition efficiencies determined using impedance spectroscopy method in $3 \% \mathrm{KOH}$ medium at $25^{\circ} \mathrm{C}$.

\begin{tabular}{cccc}
\hline Inhibitor & $\mathbf{C}_{\mathbf{i n h}}(\boldsymbol{\%})$ & $\mathbf{R}_{\mathbf{p}}\left(\mathbf{k} \mathbf{\Omega} \mathbf{c m}^{\mathbf{2}}\right)$ & $\eta \%$ \\
\hline $3 \% \mathrm{KOH}$ & - & 3.6 & - \\
& 1 & 3.7 & 27.0 \\
& 2 & 6.0 & 40.0 \\
& 3 & 8.1 & 55.6 \\
& 4 & 11.0 & 67.3 \\
& 6 & 5.5 & 34.5 \\
& 7 & 4.4 & 18.2 \\
\hline
\end{tabular}

These results are supported with SEM graphs. Figure 9 shows the SEM image of bare steel. The SEM images of the steel in $3 \% \mathrm{KOH}$ medium and by adding $4 \% \mathrm{Na}_{2} \mathrm{~B}_{4} \mathrm{O}_{7}$ are given in Figures 10 and 11, respectively. As can be seen from these images, in the presence 
of inhibitor, the surface is blocked. The same graphs were obtained in $5 \% \mathrm{KOH}$ media; they can be seen in Figures 12 and 13.

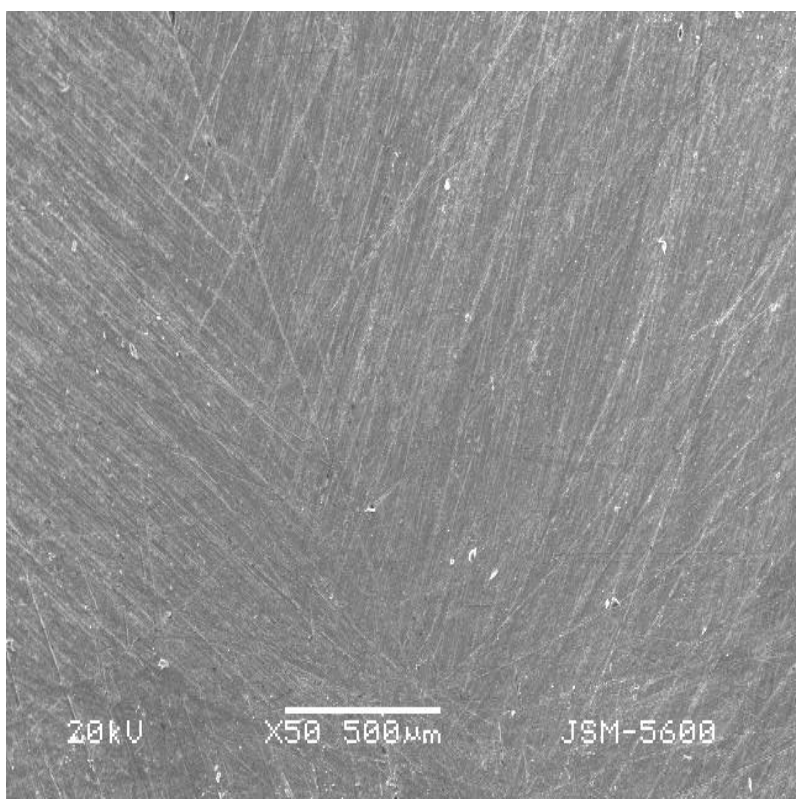

Figure 9. The SEM image of bare steel.

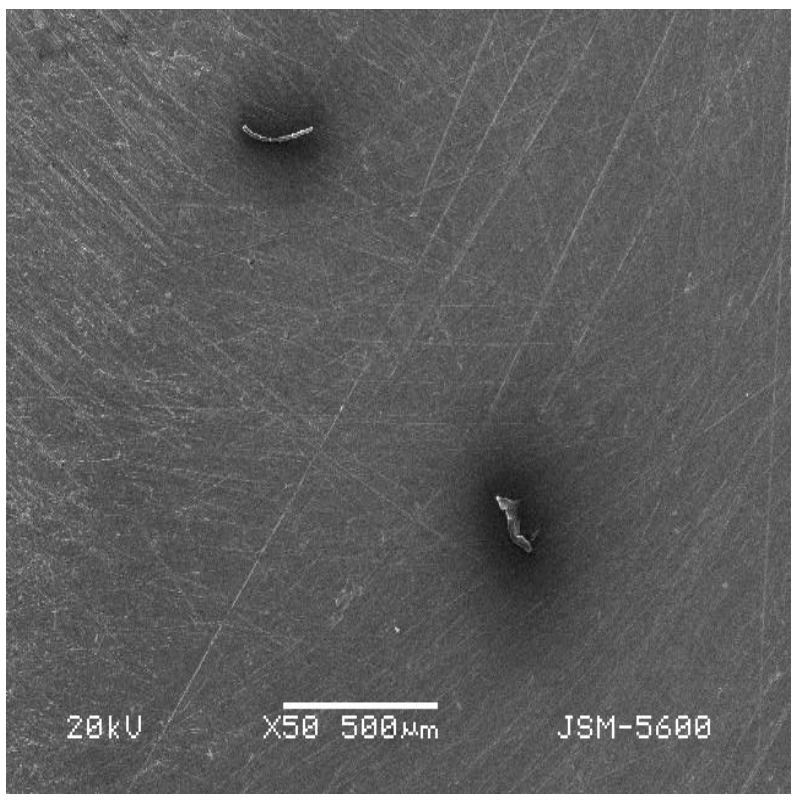

Figure 10. The SEM image of steel in 3\% $\mathrm{KOH}$ medium. 




Figure 11. The SEM image of steel in $3 \% \mathrm{KOH}$ medium by the adding of $4 \% \mathrm{Na}_{2} \mathrm{~B}_{4} \mathrm{O}_{7}$.

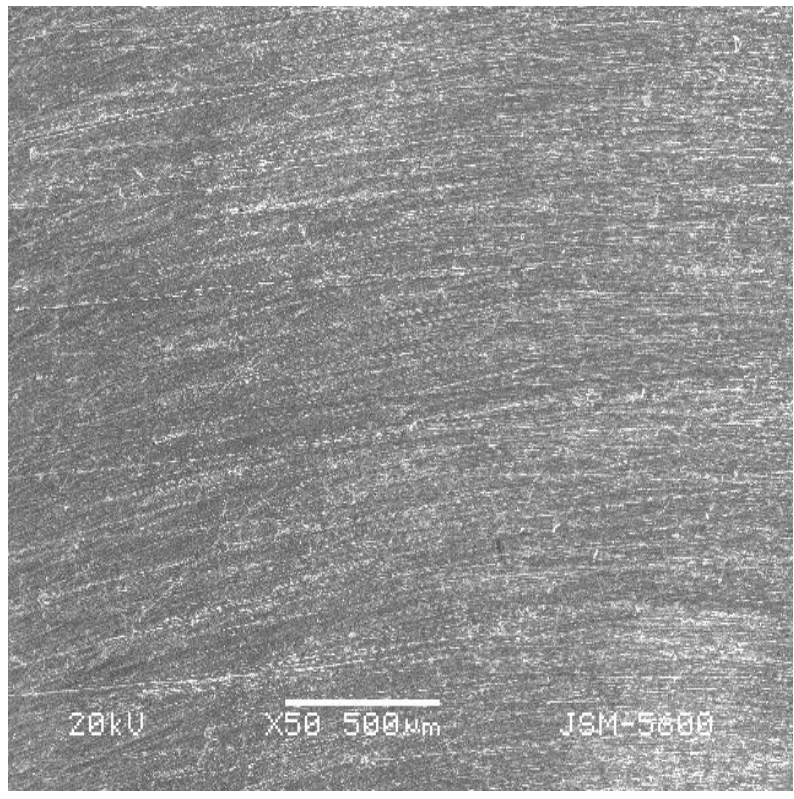

Figure 12. The SEM image of steel in 5\% $\mathrm{KOH}$ medium.

In these SEM images, like in all basic media, pitting corrosion is seen on the electrode surface.

These results can be explained with the structure of sodium tetraborate in aqueous medium (Figure 14) [29-31]. As is seen from the structure, the compound shows properties of both Lewis acid and Lewis base. Thus, it is capable of forming complexes. In 
both $\mathrm{KOH} \%$ solutions, the increase of inhibition efficiencies in the concentration range of $1 \%-4 \%$ depends on negative charge of borate which provides a basic character for this molecule. The surface covering effect of $\mathrm{Na}_{2} \mathrm{~B}_{4} \mathrm{O}_{7}$ at the aforementioned concentration range becomes clear. However, the compound losses this protective effect by combining with $\mathrm{KOH}$ at the concentration range of $5 \%-7 \%$. With increasing concentration of $\mathrm{Na}_{2} \mathrm{~B}_{4} \mathrm{O}_{7}, \mathrm{Fe}^{2+}$ ions are held by borate and replace $\mathrm{Na}^{+}$with $\mathrm{Fe}^{2+}$ ions in the complex.

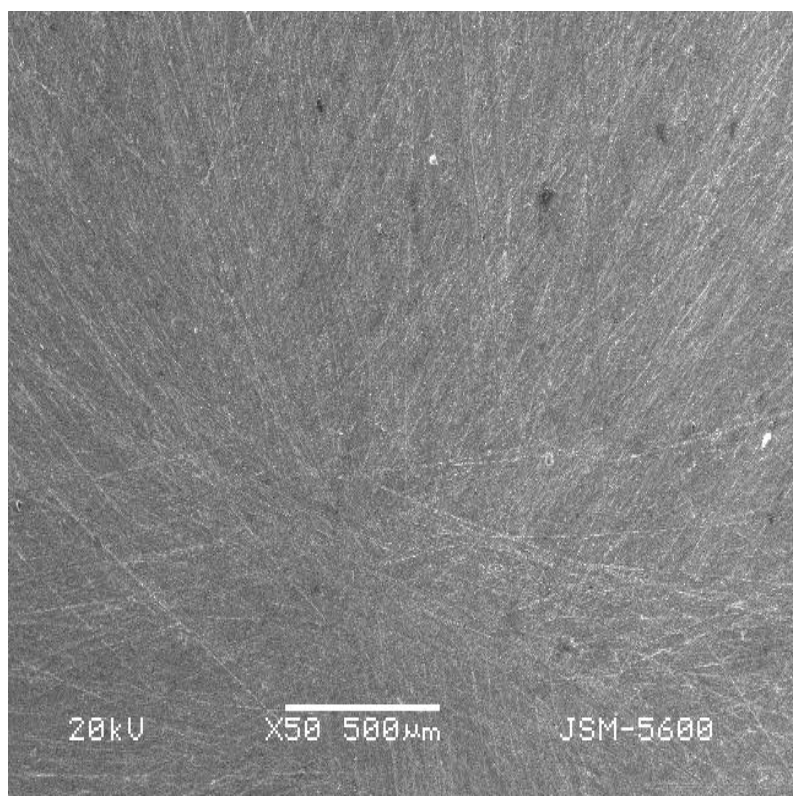

Figure 13. The SEM image of steel in $5 \% \mathrm{KOH}$ medium by the adding of $4 \% \mathrm{Na}_{2} \mathrm{~B}_{4} \mathrm{O}_{7}$.

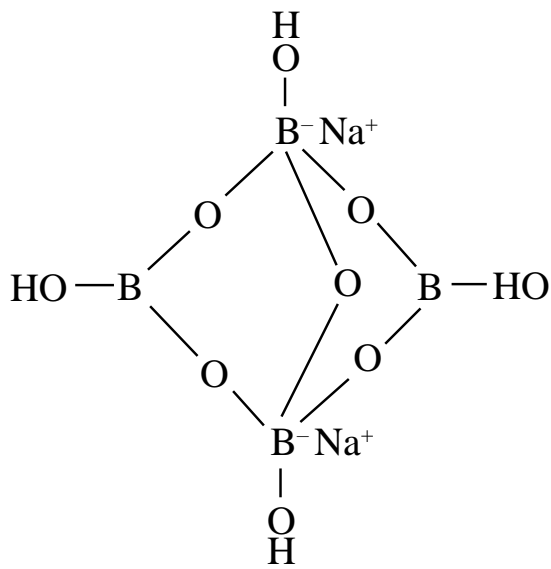

Figure 14. The chemical structure of $\mathrm{Na}_{2} \mathrm{~B}_{4} \mathrm{O}_{7}$ in aqueous medium.

In the study, the evolution of $\mathrm{H}_{2}$ was also determined. Because $\mathrm{H}_{2}$ evolution reaction occurs at the steel electrode by reduction of water molecules in aqueous medium. $\mathrm{H}_{2}$ and $\mathrm{O}_{2}$ gas quantities released by the addition of $1 \%-7 \%$ concentrations of inhibitors at a 
constant potential of $24 \mathrm{~V}$ in $3 \%$ and $5 \% \mathrm{KOH}$, in which steel is used as an electrode in a manufactured bipolar 6-cell electrolysis unit, can be seen in Tables 7 and 8. In Table 7, $\mathrm{H}_{2}$ and $\mathrm{O}_{2}$ evolution rates in $3 \% \mathrm{KOH}$ are given according to inhibitor concentrations. In Figure $15, \mathrm{H}_{2}$ and $\mathrm{O}_{2}$ gas volumes evolved in $3 \% \mathrm{KOH}$ with changing inhibitor concentration are shown. $\mathrm{H}_{2}$ and $\mathrm{O}_{2}$ evolution rates in $5 \% \mathrm{KOH}$ are also obtained and the results are seen in Table 8 and Figure 16, respectively.

Table 7. The evolution values of $\mathrm{H}_{2}$ and $\mathrm{O}_{2}$ gases depending on inhibitor concentrations in $3 \% \mathrm{KOH}$ solution.

\begin{tabular}{cccc}
\hline $\begin{array}{c}\text { Inhibitor concentration } \\
(\boldsymbol{\%})\end{array}$ & \multicolumn{2}{c}{ Formation of gases $\left(\mathbf{m L} \mathbf{~ m i n}^{\mathbf{- 1}}\right)$} & Current (A) \\
\hline 0 & $\mathbf{H}_{\mathbf{2}}$ & $\mathbf{O}_{\mathbf{2}}$ & 3 \\
1 & 226 & 113 & 3 \\
2 & 225 & 112 & 3 \\
3 & 220 & 110 & 3 \\
4 & 212 & 106 & 3 \\
5 & 210 & 105 & 3 \\
6 & 203 & 101 & 3 \\
7 & 204 & 102 & 3 \\
\hline
\end{tabular}

Table 8. The evaluation values of $\mathrm{H}_{2}$ and $\mathrm{O}_{2}$ gases depending on inhibitor concentrations in $5 \% \mathrm{KOH}$ solution.

\begin{tabular}{cccc}
\hline $\begin{array}{c}\text { Inhibitor concentration } \\
(\%)\end{array}$ & \multicolumn{2}{c}{ Formation of gases $\left(\mathbf{m L ~ m i n}^{\mathbf{- 1}}\right)$} & Current (A) \\
\hline 0 & $\mathbf{H}_{\mathbf{2}}$ & $\mathbf{O}_{\mathbf{2}}$ & 3 \\
1 & 238 & 119 & 3 \\
2 & 231 & 115 & 3 \\
3 & 224 & 112 & 3 \\
4 & 215 & 107 & 3 \\
5 & 215 & 107 & 3 \\
6 & 218 & 109 & 3 \\
7 & 216 & 108 & 3 \\
\hline
\end{tabular}






Figure 15. The evolution of $\mathrm{H}_{2}$ and $\mathrm{O}_{2}$ gasses by the addition of $1 \%-7 \%$ concentrations of inhibitors in $3 \% \mathrm{KOH}$. $(\bullet) \mathrm{H}_{2},(\boldsymbol{\square}) \mathrm{O}_{2}$.

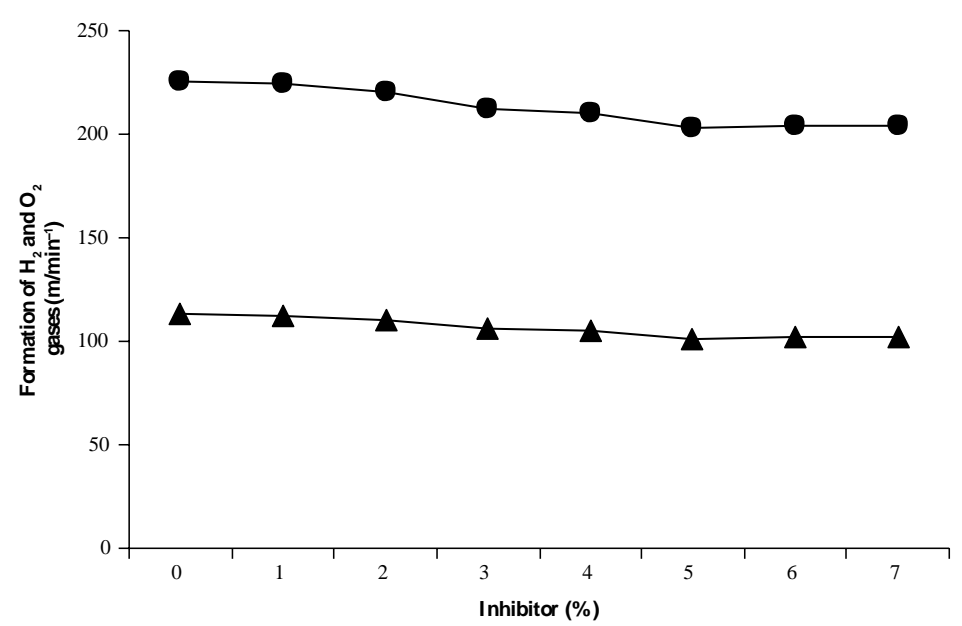

Figure 16. The evolution of $\mathrm{H}_{2}$ and $\mathrm{O}_{2}$ gases by the addition of $1 \%-7 \%$ concentrations of inhibitors in $5 \% \mathrm{KOH}$. (•) $\mathrm{H}_{2},(\boldsymbol{\Delta}) \mathrm{O}_{2}$.

As can be seen from the tables and figures, in both $\mathrm{KOH}$ concentrations the amount of evolved $\mathrm{H}_{2}$ gas first decreases, and then it remains almost constant (especially in 5\% $\mathrm{KOH}$ ). The amount of hydrogen evolved with cathodic reaction is proportional to the corrosion rate of steel. Initially the corrosion rate is fast, but with increasing amount of added $\mathrm{Na}_{2} \mathrm{~B}_{4} \mathrm{O}_{7}$ evolved $\mathrm{H}_{2}$ decreases, that is, the corrosion rate decreases. These results are in conformity with the literature results $[32,33]$.

To the extent of metal dissolution, that is, the corrosion rate, a decrease is observed in the rate of $\mathrm{H}_{2}$ gas evolution. 


\section{Conclusions}

The results of this study can be drawn as follows:

1. $\mathrm{Na}_{2} \mathrm{~B}_{4} \mathrm{O}_{7}$ affects as an inhibitor for the corrosion of the steel in $3 \% \mathrm{KOH}$ and $5 \% \mathrm{KOH}$ media, however, the corrosion rates in $1 \%-4 \%$ inhibitor concentrations have been found to be higher than those in the concentration range of $5 \%-7 \%$.

2. The activation energies determined in both basic media increase in the presence of inhibitor.

3. The active sites on the metal surface are blocked by inhibitor. This finding is confirmed by SEM images.

4. The evolution of $\mathrm{H}_{2}$ is reduced in the concentration range of $1 \%-4 \% \quad \mathrm{Na}_{2} \mathrm{~B}_{4} \mathrm{O}_{7}$, however, this variation is less in the concentration range of $5 \%-7 \%$, and it is approximately constant.

5. Results obtained using Tafel extrapolation method are in accordance with the impedance spectroscopy method.

\section{Acknowledgement}

The authors are grateful to Dr. Mükerrem Şahin from Yıldırım Beyazıt University and Dr. Gökhan Gece from Bursa Technical University for their technical assistance.

\section{References}

1. G. Trabanelli, Corrosion, 1991, 47, 410.

2. C.G. Dariva and A.F. Galio, Corrosion Inhibitors - Principles, Mechanism and Applications, Ch. 16, Intech, 2014.

3. Y.I. Kuznetsov, Organic Inhibitors. Inhibitors of Corrosion of Metals, Plenum Press, New York, 1996.

4. K.C. Emregül, A.A. Akay and O. Atakol, Mater. Chem. Phys., 2005, 93, 325.

5. O.R. Khalifa and S.M. Abdallah, Port. Electrochim. Acta, 2011, 29, 47.

6. I.A. Zaafarany, Int. J. Corros. Scale Inhib., 2014, 3, 12. doi: 10.17675/2305-68942014-3-1-012-027

7. S.K. Shukla, A.K. Singh and M.A. Quraishi, Int. J. Electrochem Sci., 2012, 7, 3371.

8. M. Osial and D. Vilinski, J. Build. Chem., 2016, 1, 42.

9. A.S. Fouda and A.S. Ellithy, Corros. Sci., 2009, 51, 868.

10. M. Finsğar and J. Jackson, Corros. Sci., 2014, 86, 17.

11. Z. Liu, L. Yu and Q. Li, J. Wuhan. Univ. Tech. Mater-Sci., 2015, 30, 325.

12. D. Parakash, R.K. Singh and R. Kumari, Ind. J. Chem. Technol., 2006, 13, 555.

13. L. Valek, S. Martinez, M. Serdar and I. Stipanovic, Chem. Biochem. Eng. Q, 2007, 21, 65. 
14. S.I. Durawaye, O.I. Sekunowo and V.O. Durowaye, Am. J. Mater. Sci., 2014, 4, 111. 15. R.O. Khalifa and S.M. Abdallah, Port. Electrochim. Acta, 2011, 29, 47. 16. S. Banerjee, V. Srivastara and M.M. Singh, Corros. Sci., 2012, 59, 35.

17. M.A. Stranick, J. Sci. Eng., 1984, 40, 296.

18. M. Hayyan, A. Shatha, H. Adeeb and I.M. Al Nashef, Int. J. Electrochem. Sci., 2012, 7, 6941.

19. R.D. Armstrong, L. Peggs and A. Walsh, J. Appl. Electrochem., 1994, 24, 1244.

20. O. Tanane, Y. Abboud, H. Aitenneite and A. El Bouari, J. Mater. Environ., 2016, 7, 131.

21. S. Karim, C.M. Mustafa, M.D. Assaduzzaman and M. Islam, Chem. Eng. Res. Bull., 2010, 14, 87.

22. A.S. Afolabi and J. Borode, Int. J. Ind. Chem., 2010, 1, 11.

23. Z. Szklarska-Smialowska and J. Marikowski, Corros. Eng. Sci. Tech., 1969, 4, 271.

24. P.S. Lees, Environ. Health Persp., 1991, 92, 93.

25. A.D. Dayan and A.J. Paine, Human Environ. Toxicol., 2001, 20, 439.

26. Y. Yashihisa and T. Shimizu, Derm. Res. Pract., 2012, Article ID 749561.

27. S.M. El-Sherbini, M.A. Abd El Wahab, M. Amin, A. Amin and M.A. Deyab, Corros. Sci., 2006, 48, 1885.

28. O. Lahodny-Sarc and S. Popov, Surf. Coat. Technol., 1988, 34, 537.

29. J.D. Le, A New Concise Inorganic Chemistry, Van Nostrand Reinhold, UK, 1977.

30. F.A. Cotton and G. Wilkinson, Basic Inorganic Chemistry, John Wiley \& Sons, Inc., Canada, 1976, p. 116.

31. A.G. Sharpe, Inorganic Chemistry, Longman, New York, 1986, p. 278.

32. E.E. Ebenso, H. Alema, S.A. Umoren and I.B. Obot, Int. J. Electrochem. Sci., 2008, 3, 1325.

33. D.R. Banjade, S.D. Porter, B. McMullan and J.N. Harb, J. Electrochem Soc., 2016, 163, C116. 